\title{
Urban and peri-urban agriculture in the global food security conundrum
}

\author{
Review by Innocent Awasom * \\ Texas Tech University Libraries
}

\section{Food Gardens for \\ a Changing World}

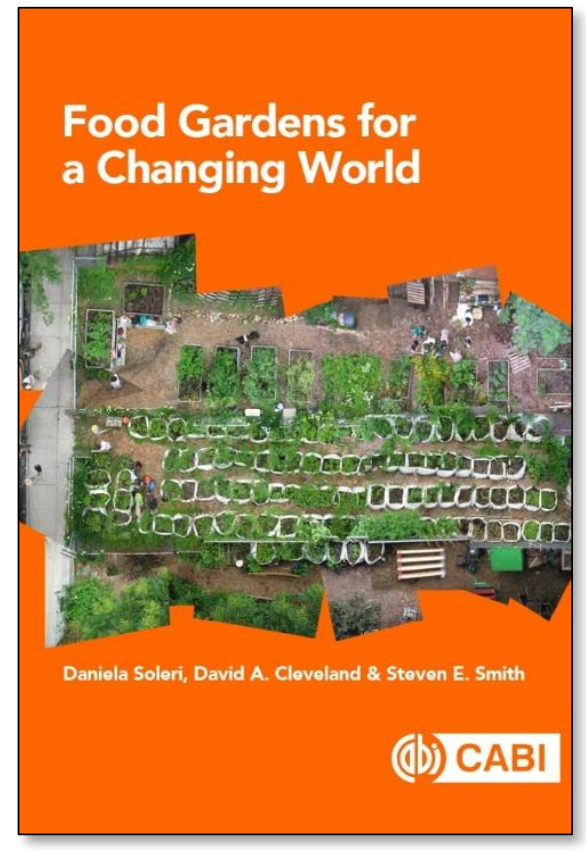

Review of Food Gardens for a Changing World, by Daniela Soleri, David A. Cleveland, and Steven E. Smith. (2019). CABI. Available as paperback, hardcover, ePDF, ePub, and Kindle; 327 pages. Publisher's website: https://www.cabi.org/bookshop/book/9781789240993

Submitted June 23, 2021 / Revised September 26, 2021 / Published online November 4, 2021

Citation: Awasom, I. (2021). Urban and peri-urban agriculture in the global food security conundrum [Book review]. Journal of Agriculture, Food Systems, and Community Development, 11(1), 209-210. https://doi.org/10.5304/jafscd.2021.111.006

Copyright (C) 2021 by the Author. Published by the Lyson Center for Civic Agriculture and Food Systems. Open access under CC-BY license.

$\mathrm{R}$ ural exodus and increased urbanization have led to the development of urban slums in major cities across the world, resulting in food insecurity. Food deserts and food pantries are cropping up in the developed world as famine and malnutrition ravage parts of the developing world, exacerbated by endless conflicts. Therefore, food systems and value chains are facing pressures and are increasingly vulnerable due to strains on natural

* Innocent Awasom, STEM Librarian, Texas Tech University Libraries, Lubbock, TX 79409 USA: awasom.afuh@ttu.edu

Innocent Awasom is associate librarian and liaison to the College of Agricultural Sciences and Natural Resources (CASNR), the department of chemistry and biochemistry, and the department of biological sciences at Texas Tech University. He holds graduate degrees in information and environmental sciences (hydrobiology and fisheries). He also dabbles in backyard food gardens and community supported agricultural (CSA) activities and adventures thanks to Master Gardeners in the Lubbock municipality. ecosystems and the impact of climate change. These strains have impacted not only land use, but also soil quality, leading to reduced quantity and quality of food available at reasonable costs to the urban poor. Thus, there is an urgent need for creative methods of food production in the urban centers to improve the sustainable food supply value chain. Food gardens as part of urban agriculture have the potential to mitigate the rise in hunger and food insecurity as it has inherent health, sociocultural, environmental, and economic benefits as documented by Lawson (2005) and in Soleri, Cleveland, and Smith's Food Gardens for a Changing World. Urban food gardens provide fresh, nutritious food that alleviates hunger and improves the health and wellbeing of the local community-plus any excess produce can be sold for additional income. Food gardens improve urban environmental quality and carbon footprint, and add value as 
places of community connection, networking, and empowerment.

Food Gardens for a Changing World is a gardener's handbook that offers practical guidance on gardening processes. It offers guidance in the biological (seed selection and growth) ecological (biotic and abiotic factors), and social aspects of the gardening process, such as interaction with other farmers, extension agents, and scientists.

Food Gardens for a Changing World offers unique and practical insight into how urban gardening can alleviate food insecurity and other problems affecting the urban poor. In a step-by-step manner, Soleri, Cleveland, and Smith show how the proliferation of urban agriculture among amateur farmers, supervised by extension experts and knowledgeable community elders, yields dividends for all concerned. The book is written in response to changing dynamics in the global food system (land, climate, population growth, rural exodus) and public health emergency (diet-related diseases such as diabetes, obesity, etc.). It uses examples from across many agro-ecological zones, from Mexico to the U.S. to Ghana.

The book consists of 10 chapters, organized into three parts. Part one consists of three chapters providing a big picture about food gardens- the socio-economic, ecological, cultural, and health benefits to a community. Part two is made up of three chapters that give specific practical advice, such as starting the garden, basic plant biology, and management and propagation under various gardening scenarios. Part three consists of four chapters on general garden management principles and practice, including material on soils, pests, and seed conservation. The chapters reflect expert indigenous knowledge from the locals and scientists in formal and informal settings, at individual or institutional levels where sustainability and social justice are part of the final equation. This is another hall- mark of the book. Each chapter has website resources and references, with a combined bibliography at the end, including an index to facilitate information retrieval. The book also contains lots of figures and illustrations to facilitate learning and comprehension.

Many books have been written on food gardens and urban agriculture. None weaves a compelling and practical gardening research narrative into an ecological and social context following the garden's evolution to the selection of diverse seeds suited to the environment to prosocial behavior and social justice dimensions as Food Gardens for a Changing World does. The book is an engaging and comprehensive gardener's handbook and reference textbook that contains innovative agricultural ideas with examples and illustrations that facilitate immediate implementation. The examples are taken from across the agro-ecological zones, hence its global appeal as a universal handbook for advanced high school and college students taking courses in sustainable food systems or agroecology. An agricultural enthusiast could read the book in order and apply as needed, while practitioners, agricultural extension agents, or Master Gardeners may use the chapters in any order as needed for application at whatever stage they are in the gardening or instruction process. For more global appeal, it would be wonderful if the book were translated into other languages such as Arabic, Chinese, French, Portuguese, and Spanish.

This is a book for the times because food security is a major global concern. There is a need to improve on and diversify the channels of food production using all available spaces, including those in urban areas. I highly recommend this book to public and private schools, academic libraries, and individuals interested in gardening and food security issues and environmental and social justice.

\section{References}

Atkinson, N. J., \& Urwin, P. E. (2012). The interaction of plant biotic and abiotic stresses: From genes to the field. Journal of Experimental Botany, 63(10), 3523-3543. https://doi.org/10.1093/jxb/ers100

Lawson, L. J. (2005). City bountiful: A century of community gardening in America. University of California Press.

United Nations Department of Economic and Social Affairs. (2021). Population, food security, nutrition and sustainable development (UN/DESA Policy Brief No. 102. https://www.un.org/development/desa/dpad/publication/undesa-policy-brief-102-population-food-security-nutrition-and-sustainable-development/ 